\title{
The Measurement of the Agricultural Informatization Contribution Rate Based on the Analysis of the Composite Index and the C-D Production Function
}

\author{
Liyong Liu and Daoliang Li \\ College of Information and Electrical Engineering, China Agricultural University, PRC.100083 \\ P.O. Box 121, College of Information and Electrical Engineering, China Agricultural University, \\ 17 Tsinghua East Road, Beijing, 100083, P.R. China
}

\begin{abstract}
The agricultural informatization contribution rate is the proportion of the contribution of agricultural informatization to the algebraic summation of agricultural economy growth accounting for the agricultural economy growth. It is a comprehensive index which reflects the function of agricultural informatization in enhancing agricultural productivity and agricultural economy development. This paper combines the analysis of the composite index with C-D production function to measure the contribution rate of agricultural informatization. Firstly this paper is going to establish the agricultural information evaluation index system including the infrastructure, resources, application, personnel, and policy environment. Then it is going to calculate each index and the composite index of agricultural informatization by means of synthetic rating analysis. Based on the above, this paper is going to build up a C-D production function model to measure the agricultural informatization contribution rate by regression function.
\end{abstract}

Keywords: Agricultural Informationalization, Contribution rate, C-D production function.

\section{Introduction}

The agricultural informatization contribution rate is the proportion of the contribution of agricultural informatization to the algebraic summation of agricultural economy growth accounting for the agricultural economy growth. It is a comprehensive index which reflects the function of agricultural informatization in enhancing agricultural productivity and agricultural economy development. (Liu, 2011). Its calculation method is shown as Formula (1):

\section{Agricultural informatization conbrituion rate $(\%)$}

$=\frac{\text { the contribution of agricultural informatization to the algebraic summation of agricultural economy growth }}{\text { the overall growth of agricultural economy }}$

\section{$\times 100 \% \quad$ Formula $(1)$}

However agricultural informatization is a complex system which has too many influencing factors to be calculated directly. Therefore it is essential to establish a feasible way to measure the agricultural informatization indirectly in order to meet 
practical needs. Hence this paper is going to identify agricultural informatization indices, discuss the relation of agricultural informatization and agricultural economic growth, and finally set up the measure method for agricultural informatization.

\section{Establishing the Agricultural Informatization Evaluation Index System}

An index system scientific enough to truly reveal the object should be able to cover indices all-sidedly. Based on the comprehensiveness, scientificalness, objectivity, practicability, and systematicness principles of index, combining the practice of China's agricultural informatization and related statistical yearbooks, China's agricultural informatization evaluation index system should consist of five indices: the infrastructure $(\mathrm{F})$, resources $(\mathrm{R})$, application $(\mathrm{A})$, personnel $(\mathrm{H})$, and policy environment (E) and 19 sub-indices.

\subsection{The Infrastructure of Agricultural Informatization (F)}

The infrastructure of agricultural informatization is the hardware basis and neural system of agricultural informatization; it is also the precondition for the functioning of agricultural information resources and technologies; and the infrastructure of agricultural informatization is composed of traditional network (postal network, television and radio network, and telephone and mobile network), and modern information network (internet services and computer equipment). The infrastructure of agricultural informatization enables people to transmit information beyond geographical and temporal constraints and facilitates the collaboration through resource sharing. In this paper the infrastructure of agricultural informatization includes five sub-indices, which are the population coverage of radio, the population coverage of television, telephone density, mobile phone penetration rate, and family computers with internet access (Zhao, 2007).

\subsection{Resources of Agricultural Informatization (R)}

Resources of agricultural informatization are the content carried by the infrastructure of agricultural informatization. It involves document, information, diagrams and data, and demonstrates connections of various subjects and inherent laws. This index includes two aspects of document information content and digital information resources covering four sub-indices of agricultural book types, publishing newspaper and magazines, libraries and websites.

\subsection{The Application of Agricultural Informatization (A)}

Information technologies are essential to the development of informatization. Not only fundamentally change the form and content of human information activities, information technologies but also strong impact on people's lifestyle, behaviour 
pattern, and thinking and production mode (TKularahte, 1999). Moreover the application of information technologies into the agriculture serves the purpose of agricultural informatization which is accelerating the development of agriculture, rural area and farmers. Therefore in this paper three sub-indices, the population of netizens in rural area, number of key agricultural scientific and technological achievements, and the aggregation of tele-service in rural area (Gao, 2009).

\subsection{Personnel in Agricultural Informatization (H)}

Personnel in informatization have a decisive role in informatization and is a significant condition securing the success of informatization construction. This paper studies this issue by looking at personnel in scientific activities, communication and transportation, education and culture, radio and television, computer service and software development. As a result this paper selects the population taking up scientific activities out of ten thousand people, the population in information transmission by computer service and software industry, the population in transportation, logistics and telecommunication industry, and the population in education, cultural, art, television and radio sector, as four sub-indices to evaluation the personnel in agricultural informatization (Yu, 2007).

\subsection{The Policy Environment of Agricultural Informatization (E)}

A favourable policy environment facilitates the informatization development as the informatization is a complex system which is influenced by the society, the state and the government $(\mathrm{Li}, 2009)$. Policies in papers refer to those laws, regulations, and policies made by legislatures, administrative authorities, and other related authorities in order to coordinate and accelerate the informatization, and those fund and supplies allocated by the government to support the informatization. Therefore this paper uses the proportion of S\&T expenditure in GDP, local government fund for S\&T, and the proportion of local government fund for $S \& T$ in the total expenditure of local government as three sub-indices to assess the government support to agricultural informatization.

\section{Testing Indices of Agricultural Informatization}

This paper measures the development of agricultural informatization by synthetic rating analysis. First of all, this paper uses Delphi method to determine the weight of each index and sub-index in the index system which is demonstrated by Table 1 . All the corresponding data for indices in Table 1 can be traced in China Statistical Yearbook, China's Major S\&T Indicators Database, and China's Internet Development Survey. However this paper, as a method study, is not going to put any data into the model for calculation. 
Table 1. The evaluation index system of agricultural informatization development

\begin{tabular}{|c|c|c|}
\hline Index & Sub-index & No. \\
\hline \multirow{5}{*}{$\begin{array}{l}\text { 1. The infrastructure of } \\
\text { agricultural informatization }\end{array}$} & 1.1 Population coverage rate of radio $(\%)$ & 1 \\
\hline & 1.2 Population coverage rate of television $(\%)$ & 2 \\
\hline & 1.3 Telephone density $(\%)$ & 3 \\
\hline & 1.4 Mobile phone penetration rate $(\%)$ & 4 \\
\hline & $\begin{array}{l}1.5 \text { Family computers with internet access (per } \\
\text { hundred households) }\end{array}$ & 5 \\
\hline \multirow{5}{*}{$\begin{array}{l}\text { 2. Resources of agricultural } \\
\text { informatization }\end{array}$} & 2.1 Agricultural book types & 6 \\
\hline & 2.2 Publishing newspaper and magazines & 7 \\
\hline & 2.3 Libraries & 8 \\
\hline & 2.4 Websites & 9 \\
\hline & $\begin{array}{l}3.1 \text { The population of netizens in rural area (ten } \\
\text { thousand) }\end{array}$ & 10 \\
\hline
\end{tabular}

3. The application of 3.2 Number of key agricultural scientific and agricultural informatization technological achievements

3.3 The aggregation of tele-service in rural area (hundred million RMB)

4.1 Population taking up scientific activities out of ten thousand people (per ten thousand people)

4.2 Population in information transmission by

4. Personnel in agricultural computer service and software industry (per ten informatization thousand people)

4.3 Population in transportation, logistics and telecommunication industry (per ten thousand people)

4.4 Population in education, cultural, art, television and radio sector (per ten thousand people)

5.1 The proportion of S\&T expenditure in GDP (\%)

5.2 Local government fund for S\&T(hundred million 5. The policy environment of agricultural informatization $\mathrm{RMB})$

5.3 The proportion of local government fund for S\&T in the total expenditure of local government $(\%)$ 


\subsection{Measuring the Indices}

For the sake of simplicity, this paper uses the measurement of the infrastructure of agricultural informatization $(\mathrm{F})$ to demonstrate the measurement method for the indices and sub-indices and obtain the final index of agricultural informatization in order to avoid repetition. The corresponding data for sub-indices under the infrastructure of agricultural informatization from 2001 to 2010 is illustrated in Table 2.

Table 2. Sub-indices under the infrastructure of agricultural informatization (2001-2010)

\begin{tabular}{llcccc}
\hline Year & $\begin{array}{c}\text { Population } \\
\text { coverage rate of } \\
\text { radio }\end{array}$ & $\begin{array}{c}\text { Population } \\
\text { coverage rate of } \\
\text { television }\end{array}$ & $\begin{array}{c}\text { Telephone } \\
\text { density }\end{array}$ & $\begin{array}{c}\text { Mobile } \\
\text { phone } \\
\text { penetration } \\
\text { rate }\end{array}$ & $\begin{array}{c}\text { Family computers } \\
\text { with internet } \\
\text { access }\end{array}$ \\
\hline 2001 & $\mathrm{~F}_{11}$ & $\mathrm{~F}_{21}$ & $\mathrm{~F}_{31}$ & $\mathrm{~F}_{41}$ & $\mathrm{~F}_{51}$ \\
2002 & $\mathrm{~F}_{12}$ & $\mathrm{~F}_{22}$ & $\mathrm{~F}_{32}$ & $\mathrm{~F}_{42}$ & $\mathrm{~F}_{52}$ \\
2003 & $\mathrm{~F}_{13}$ & $\mathrm{~F}_{23}$ & $\mathrm{~F}_{33}$ & $\mathrm{~F}_{43}$ & $\mathrm{~F}_{53}$ \\
2004 & $\mathrm{~F}_{14}$ & $\mathrm{~F}_{24}$ & $\mathrm{~F}_{34}$ & $\mathrm{~F}_{44}$ & $\mathrm{~F}_{54}$ \\
2005 & $\mathrm{~F}_{15}$ & $\mathrm{~F}_{25}$ & $\mathrm{~F}_{35}$ & $\mathrm{~F}_{45}$ & $\mathrm{~F}_{55}$ \\
2006 & $\mathrm{~F}_{16}$ & $\mathrm{~F}_{26}$ & $\mathrm{~F}_{36}$ & $\mathrm{~F}_{46}$ & $\mathrm{~F}_{56}$ \\
2007 & $\mathrm{~F}_{17}$ & $\mathrm{~F}_{27}$ & $\mathrm{~F}_{37}$ & $\mathrm{~F}_{47}$ & $\mathrm{~F}_{57}$ \\
2008 & $\mathrm{~F}_{18}$ & $\mathrm{~F}_{28}$ & $\mathrm{~F}_{38}$ & $\mathrm{~F}_{48}$ & $\mathrm{~F}_{58}$ \\
2009 & $\mathrm{~F}_{19}$ & $\mathrm{~F}_{29}$ & $\mathrm{~F}_{39}$ & $\mathrm{~F}_{49}$ & $\mathrm{~F}_{59}$ \\
2010 & $\mathrm{~F}_{10}$ & $\mathrm{~F}_{20}$ & $\mathrm{~K}_{30}$ & $\mathrm{~K}_{40}$ & $\mathrm{~K}_{50}$ \\
\hline
\end{tabular}

All the data need to be processed with dimensionless method prior to calculation in order to unify units. As Table 3 shows, this paper sets the year 2001 as the benchmark and all the index data in this year as 1 , then divides the absolute value of each index data in year $t$ by the corresponding index data in the benchmark year, and obtains the dimensionless value of each index in year $\mathrm{t}$. 
Table 3. The dimensionless processing of sub-indices under the infrastructure of agricultural informatization (2001-2010)

\begin{tabular}{lccccc}
\hline Year & $\begin{array}{c}\text { Population } \\
\text { coverage rate of } \\
\text { radio }\end{array}$ & $\begin{array}{c}\text { Population } \\
\text { coverage rate of } \\
\text { television }\end{array}$ & $\begin{array}{c}\text { Telephone } \\
\text { density }\end{array}$ & $\begin{array}{c}\text { Mobile phone } \\
\text { penetration } \\
\text { rate }\end{array}$ & $\begin{array}{c}\text { Family computers } \\
\text { with internet access }\end{array}$ \\
\hline 2001 & 1 & 1 & 1 & 1 & 1 \\
2002 & $\mathrm{~F}_{12} / \mathrm{F}_{11}$ & $\mathrm{~F}_{22} / \mathrm{F}_{21}$ & $\mathrm{~F}_{32} / \mathrm{F}_{31}$ & $\mathrm{~F}_{42} / \mathrm{F}_{41}$ & $\mathrm{~F}_{52} / \mathrm{F}_{51}$ \\
2003 & $\mathrm{~F}_{13} / \mathrm{F}_{11}$ & $\mathrm{~F}_{23} / \mathrm{F}_{21}$ & $\mathrm{~F}_{33} / \mathrm{F}_{31}$ & $\mathrm{~F}_{43} / \mathrm{F}_{41}$ & $\mathrm{~F}_{53} / \mathrm{F}_{51}$ \\
2004 & $\mathrm{~F}_{14} / \mathrm{F}_{11}$ & $\mathrm{~F}_{24} / \mathrm{F}_{21}$ & $\mathrm{~F}_{34} / \mathrm{F}_{31}$ & $\mathrm{~F}_{44} / \mathrm{F}_{41}$ & $\mathrm{~F}_{54} / \mathrm{F}_{51}$ \\
2005 & $\mathrm{~F}_{15} / \mathrm{F}_{11}$ & $\mathrm{~F}_{25} / \mathrm{F}_{21}$ & $\mathrm{~F}_{35} / \mathrm{F}_{31}$ & $\mathrm{~F}_{45} / \mathrm{F}_{41}$ & $\mathrm{~F}_{55} / \mathrm{F}_{51}$ \\
2006 & $\mathrm{~F}_{16} / \mathrm{F}_{11}$ & $\mathrm{~F}_{26} / \mathrm{F}_{21}$ & $\mathrm{~F}_{36} / \mathrm{F}_{31}$ & $\mathrm{~F}_{46} / \mathrm{F}_{41}$ & $\mathrm{~F}_{56} / \mathrm{F}_{51}$ \\
2007 & $\mathrm{~F}_{17} / \mathrm{F}_{11}$ & $\mathrm{~F}_{27} / \mathrm{F}_{21}$ & $\mathrm{~F}_{37} / \mathrm{F}_{31}$ & $\mathrm{~F}_{47} / \mathrm{F}_{41}$ & $\mathrm{~F}_{57} / \mathrm{F}_{51}$ \\
2008 & $\mathrm{~F}_{18} / \mathrm{F}_{11}$ & $\mathrm{~F}_{28} / \mathrm{F}_{21}$ & $\mathrm{~F}_{38} / \mathrm{F}_{31}$ & $\mathrm{~F}_{48} / \mathrm{F}_{41}$ & $\mathrm{~F}_{58} / \mathrm{F}_{51}$ \\
2009 & $\mathrm{~F}_{19} / \mathrm{F}_{11}$ & $\mathrm{~F}_{29} / \mathrm{F}_{21}$ & $\mathrm{~F}_{39} / \mathrm{F}_{31}$ & $\mathrm{~F}_{49} / \mathrm{F}_{41}$ & $\mathrm{~F}_{59} / \mathrm{F}_{51}$ \\
2010 & $\mathrm{~F}_{10} / \mathrm{F}_{11}$ & $\mathrm{~F}_{20} / \mathrm{F}_{21}$ & $\mathrm{~K}_{30} / \mathrm{F}_{31}$ & $\mathrm{~K}_{40} / \mathrm{F}_{41}$ & $\mathrm{~K}_{50} / \mathrm{F}_{51}$ \\
\hline
\end{tabular}

For simplicity, we set the weight of each index to equal. Since there are five sub-indices under the infrastructure of agricultural informatization, the weight of each index is $\mathrm{Pi}=0.2$. Then we can use Formula (2) to calculate IIF which is the annual index value for infrastructure of agricultural informatization:

$$
I I_{F}=\sum^{n} P_{i} W_{i}
$$

Formula (2)

In Formula (2), $\mathrm{Pi}$ is the weight of each index, and the mean of each third-class index under the infrastructure of agricultural informatization is given 0.2 . Wi is the dimensionless value of index $\mathrm{i}$, and $\mathrm{n}$ is the amount of indices in the index system, which is five in this formula.

\subsection{Measuring the Overall Index}

Likewise, four index value, IIR, IIA, IIH, and IIE can be calculated for the other four indices which are resources, application, personnel and policy environment. Then we adopt Formula (3) which is listed below to find out the index II, the overall index of agricultural informatization.

$$
I I=\sum_{i=1}^{n}\left(\sum_{j=1}^{m_{i}} P_{i j} W_{i j}\right) \cdot W_{i}
$$

Formula(3)

Hereby, II is the overall index value of regional agricultural informatization; $\mathrm{n}$ is the amount of first-class indices in the evaluation system; mi is the amount of sub-indices under the index $\mathrm{i}$; Wij is the standardized value of sub-index $\mathrm{j}$ under the first-class 
index $\mathrm{i}$; and Pij is the weight of sub-index $\mathrm{j}$ accounting in the first-class index which it belongs to.

\section{Measuring the Agricultural Informatization Contribution Rate by C-D Production Function}

\subsection{Model Establishment}

Charles Cobb and Paul Dauglas break the hypothesis of fixed capital-output ratio and capital-saving ratio raised by Harrod-Domar model and establish C-D production function is established by to analyse the relation of input and output in a simple way. In general C-D production function divides the input into capital and labour (Wang, 2010). But in order to calculate the contribution made by agricultural informatization to agricultural economic growth, this paper revises the C-D production function based on the new growth theory proposed by Paul M. Romer. Romer argues that it is not only capital and labour, but also S\&T development that should be included in C-D production function as the third element (Romer, 1994). Therefore this paper argues that information is the foremost income of S\&T development and consequently information can take the place of S\&T development to be factored in the C-D production function as the third element in the input. Hence C-D production function can be revised to Formula (4):

$$
Y=A K^{\alpha} L^{\beta} I^{\gamma}
$$

Formula(4)

Its log-linear model is:

$$
\log (Y)=\log (A)+\alpha \log (K)+\beta \log (L)+\gamma \log (I)
$$

In Formula (4) and Formula (5), $Y, K, L$, and $I$ represent the total yield of agricultural products, the quantity of capital input, the quantity of labour input, and the index of agricultural informatization respectively; $\alpha, \beta$, and $\gamma$ refer to the capital elasticity of the output, the elasticity of labour, and the elasticity of informatization respectively; $A$, which is set to be a constant, refers to the influence of other factors on agricultural economic growth except capital, labour and informatization.

\subsection{Model Regression}

All the index data adopted in the model, including the overall index I, can be calculated through the index system established in this paper; the total yield of agricultural production (Y), the fixed asset investment (K), and the population working in agriculture (L) can be looked up in China Statistical Yearbook. Then a regression model can be established as shown in Table 4. 
Table 4. The regression model matrix

\begin{tabular}{|c|c|c|c|c|c|c|c|c|c|}
\hline Year & $\begin{array}{c}\text { The } \\
\text { total } \\
\text { yield of } \\
\text { agricult } \\
\text { ural } \\
\text { producti } \\
\text { on (Y) }\end{array}$ & $\begin{array}{c}\text { The } \\
\text { fixed } \\
\text { asset } \\
\text { investm } \\
\text { ent in } \\
\text { agricult } \\
\text { ure }(\mathrm{K})\end{array}$ & $\begin{array}{l}\text { The } \\
\text { populati } \\
\text { on } \\
\text { working } \\
\text { in } \\
\text { agricult } \\
\text { ure (L) }\end{array}$ & $\begin{array}{l}\text { The } \\
\text { overall } \\
\text { index of } \\
\text { agricult } \\
\text { ural } \\
\text { informa } \\
\text { tization } \\
\text { (I) }\end{array}$ & $\begin{array}{c}\text { The } \\
\text { infrastru } \\
\text { cture of } \\
\text { agricult } \\
\text { ural } \\
\text { informa } \\
\text { tization } \\
\text { (F) }\end{array}$ & $\begin{array}{l}\text { Resourc } \\
\text { es of } \\
\text { agricult } \\
\text { ural } \\
\text { informa } \\
\text { tization } \\
\text { (R) }\end{array}$ & $\begin{array}{l}\text { The } \\
\text { applicat } \\
\text { ion of } \\
\text { agricult } \\
\text { ural } \\
\text { informa } \\
\text { tization } \\
\text { (A) }\end{array}$ & $\begin{array}{c}\text { Personn } \\
\text { el of } \\
\text { agricult } \\
\text { ural } \\
\text { informa } \\
\text { tization } \\
\text { (H) }\end{array}$ & $\begin{array}{l}\text { The } \\
\text { policy } \\
\text { environ } \\
\text { ment of } \\
\text { agricult } \\
\text { ural } \\
\text { informa } \\
\text { tization } \\
\text { (E) }\end{array}$ \\
\hline 2001 & $Y_{1}$ & $\mathrm{~K}_{1}$ & $\mathrm{~L}_{1}$ & $\mathrm{I}_{1}$ & $\mathrm{~F}_{1}$ & $\mathrm{R}_{1}$ & $\mathrm{~A}_{1}$ & $\mathrm{H}_{1}$ & $\mathrm{E}_{1}$ \\
\hline 2002 & $\mathrm{Y}_{2}$ & $\mathrm{~K}_{2}$ & $\mathrm{~L}_{2}$ & $\mathrm{I}_{2}$ & $\mathrm{~F}_{2}$ & $\mathrm{R}_{2}$ & $\mathrm{~A}_{2}$ & $\mathrm{H}_{2}$ & $\mathrm{E}_{2}$ \\
\hline 2003 & $Y_{3}$ & $\mathrm{~K}_{3}$ & $\mathrm{~L}_{3}$ & $\mathrm{I}_{3}$ & $\mathrm{~F}_{3}$ & $\mathrm{R}_{3}$ & $\mathrm{~A}_{3}$ & $\mathrm{H}_{3}$ & $E_{3}$ \\
\hline 2004 & $\mathrm{Y}_{4}$ & $\mathrm{~K}_{4}$ & $\mathrm{~L}_{4}$ & $\mathrm{I}_{4}$ & $\mathrm{~F}_{4}$ & $\mathrm{R}_{4}$ & $\mathrm{~A}_{4}$ & $\mathrm{H}_{4}$ & $\mathrm{E}_{4}$ \\
\hline 2005 & $\mathrm{Y}_{5}$ & $\mathrm{~K}_{5}$ & $\mathrm{~L}_{5}$ & $\mathrm{I}_{5}$ & $\mathrm{~F}_{5}$ & $\mathrm{R}_{5}$ & $\mathrm{~A}_{5}$ & $\mathrm{H}_{5}$ & $\mathrm{E}_{5}$ \\
\hline 2006 & $\mathrm{Y}_{6}$ & $\mathrm{~K}_{6}$ & $\mathrm{~L}_{6}$ & $\mathrm{I}_{6}$ & $\mathrm{~F}_{6}$ & $\mathrm{R}_{6}$ & $\mathrm{~A}_{6}$ & $\mathrm{H}_{6}$ & $\mathrm{E}_{6}$ \\
\hline 2007 & $Y_{7}$ & $\mathrm{~K}_{7}$ & $\mathrm{~L}_{7}$ & $\mathrm{I}_{7}$ & $\mathrm{~F}_{7}$ & $\mathrm{R}_{7}$ & $\mathrm{~A}_{7}$ & $\mathrm{H}_{7}$ & $E_{7}$ \\
\hline 2008 & $\mathrm{Y}_{8}$ & $\mathrm{~K}_{8}$ & $\mathrm{~L}_{8}$ & $\mathrm{I}_{8}$ & $\mathrm{~F}_{8}$ & $\mathrm{R}_{8}$ & $\mathrm{~A}_{8}$ & $\mathrm{H}_{8}$ & $\mathrm{E}_{8}$ \\
\hline 2009 & $\mathrm{Y}_{9}$ & $\mathrm{~K}_{9}$ & $\mathrm{~L}_{9}$ & $\mathrm{I}_{9}$ & $\mathrm{~F}_{9}$ & $\mathrm{R}_{9}$ & $\mathrm{~A}_{9}$ & $\mathrm{H}_{9}$ & $\mathrm{E}_{9}$ \\
\hline 2010 & $\mathrm{Y}_{10}$ & $\mathrm{~K}_{10}$ & $\mathrm{~L}_{10}$ & $\mathrm{I}_{10}$ & $\mathrm{~F}_{10}$ & $\mathrm{R}_{10}$ & $\mathrm{~A}_{10}$ & $\mathrm{H}_{10}$ & $\mathrm{E}_{10}$ \\
\hline
\end{tabular}

A linear regression analysis of $Y^{\prime}, K^{\prime}, L^{\prime}, I^{\prime}, F^{\prime}, R^{\prime}, A^{\prime}$, and $H^{\prime}$ corresponding to indices in Table 4 is conducted based on the Enter method by SPSS 13.0. The regression result is shown in Table 5. Based on the regression result, a regression model can be set up which can be sorted into a simulation equation consisting three variables, the fixed asset investment, working population in agriculture, and the overall index of agricultural informatization, another five variables regarding the five sub-indices, and the total yield of agricultural production.

Table 5. The regression result of the model (the overall index of agricultural informatization)

\begin{tabular}{ccccc}
\hline Item & Constant term & $\left(K^{\prime}\right)$ & $\left(L^{\prime}\right)$ & $\left(I^{\prime}\right)$ \\
\hline Standardized coefficient & & $a$ & $\mathrm{j}$ & $g$ \\
B & $b$ & $h$ & $w$ & $m$ \\
(T-statistic) & $t$ & $c$ & $\mathrm{f}$ & $i$ \\
R-squared & & $r^{2}$ & & \\
F-statistic & $f$ & & \\
Durbin-Watson statistic & & $d$ & & \\
\hline
\end{tabular}


According to the regression model above, we determine the fitting degree of selected samples and the entirety, and test the linearity degree of the model by F-statistic and the explanation degree of each variable to the economic growth by T-statistic. If the fitting degree, the linearity degree and the explanation degree is high, and variable $K, L, I$ and the constant term is able to meet the test at a high probability, it means that the model can meet the test as a whole and have a good simulate effect on the reality. Thus the model of agricultural economic growth is shown as Formula (6):

$$
Y^{\prime}=b+h K^{\prime}+w L^{\prime}+m I^{\prime}
$$

Formula(6)

Formula (6) can be converted into Formula (7):

$$
Y_{t}=e^{b} K_{t}^{h} L_{t}^{w} I_{t}^{m}
$$

Similarly, we can also set up regression models for the five first-class indices including the infrastructure of agricultural informatization $(\mathrm{F})$, resources of agricultural informatization (R), the application of agricultural informatization (A), and personnel of agricultural informatization $(\mathrm{H})$, and the policy environment of agricultural informatization $(E)$, which this paper won't repeat.

\section{Conclusion}

This paper finds out the standardized coefficient and the output elasticity of the three factors in agricultural economy which are capital, labour and information. From the perspective of standardized coefficient, in the regression result of the model of the overall index of agricultural informatization, the standardized coefficients of the fixed asset investment, population working in agriculture and information are $a, j$, and $g$ respectively, which can assess the influence of the three factors on agricultural economy development.

From the point of view of the output elasticity, in the regression result of the model of the overall index of agricultural informatization, the output elasticity of $K^{\prime}, L^{\prime}$, and $I$ ' are: $h, w$, and $m$. According to the definition of output elasticity, the agricultural economy increases by $m \%$ for one further percentage point of growth of agricultural informatization; whereas one further percentage point of growing of capital and labour can increase the agricultural economy by $h \%$ and $w \%$. Thus the contribution rate of agricultural informatization to the agricultural economic growth in any year can be calculated after the index of agricultural informatization is acquired.

Likewise, the contribution rate of each index in the model to agricultural economic can be measure`ed.

Acknowledgement. This paper is proudly funded by Beijing Municipal Science \& Technology Commission's Scholarship for PhD thesis in Soft Science. This article also draws on the Beijing New Rural Development Research Project (No. BJXNCJD 2011-01-1). 


\section{References}

1. TKularahte, E.D.: Information Needs and information Provision in Developing Countries. Inofation Delment 13, 9 (1997)

2. Gao, Y., Gan, G.H.: A preliminary research on the measurement index system for agricultural informatization. Agriculture Network Information 8, 49-53 (2009)

3. Li, B., Liu, L.: An empirical study on the agricultural informatization's contribution to the economic growth in Hunan Province. Economic Geography 10, 63-66 (2009)

4. Liu, F.F.: An empirical analysis on the agricultural informatization contribution based on the data envelopment analysis (DEA). Journal of Library and Information Sciences in Agriculture 2, 21-25 (2011)

5. Lu, L.N.: Constructing the measurement index system for agricultural informatization. Journal of Library and Information Sciences in Agriculture 4, 39-41 (2007)

6. Romer, P.M.: The origins of endogenous growth. Journal of Economic Perspectives 8(1-winter), 3-22 (1994)

7. Tseng, C.C., Gmytrasiewicz, P.J.: Real-time decision support and information gathering system for financial domain. Physical A: Statistical Mechanics and its Applications 363(5), 417-436 (2008)

8. Wang, L.: An empirical analysis on the informatization's contribution to the economic growth in rural area in Shandong Province. Northwest University of Farming and Forestry Technology (2010)

9. Yu, L., Geng, H.J.: A study on the measurement index system of Chinese agricultural informatization development and the measurement method. New Science 1, 33-36 (2007)

10. Zhao, H.Y., Dai, Y.M., Li, Z.H., Ding, J.B.: An empirical analysis on agricultural informatization contribution rate based on Cobb-Douglas production function. Journal of Jiangxi Agriculture University (Social Science Edition) 3, 44-49 (2009) 